\title{
Down-regulation of cobalt-induced HIF-1 $\alpha$ expression correlates with cell proliferation and apoptosis in human gastric carcinoma cells
}

\author{
TONANG DWI ARDYANTO ${ }^{1,3}$, MITSUHIKO OSAKI ${ }^{1,2}$, YUMI NAGAHAMA $^{1}$, \\ KENSAKU YAMAGA $^{1}$, NORITAKA MAETA ${ }^{1}$, TAKAYUKI TAMURA ${ }^{1}$ and HISAO ITO ${ }^{1}$
}

\begin{abstract}
${ }^{1}$ Division of Organ Pathology, Department of Microbiology and Pathology, Faculty of Medicine, Tottori University;
${ }^{2}$ Division of Molecular Genetics and Biofunction, Department of Biomedical Sciences, Tottori University Graduate School of Medical Science, Nishi-cho 86 Yonago, Tottori, 683-8503, Japan; ${ }^{3}$ Clinical Pathology Department, Faculty of Medicine, Sebelas Maret University, Jl Ir Soetami 36A, Surakarta, Jawa Tengah 57126, Indonesia
\end{abstract}

Received August 20,2007; Accepted September 28, 2007

\begin{abstract}
Previously we reported that the hypoxia-inducible factor- $1 \alpha(\mathrm{HIF}-1 \alpha)$ expression correlated with cell proliferation and apoptosis under $500 \mathrm{mM}$ of $\mathrm{CoCl}_{2}$ treatment in a human gastric carcinoma cell line, MKN-1. Herein we report a similar correlation in other cell lines, MKN-45 and TMK-1. The dual-phase expression of HIF- $1 \alpha$ was highest at 6 and 8 $\mathrm{h}$ of treatment in MKN-45 and TMK-1, respectively, while the peak in MKN-1 occurred at $4 \mathrm{~h}$. The cell viability indices showed a similar dual phase to the HIF- $1 \alpha$ expression, while the apoptotic indices started to increase as the level of the HIF- $1 \alpha$ expression decreased. In our previous study, the FACS analysis showed a marked $\mathrm{G}_{2} / \mathrm{M}$ arrest and an increase of the pre- $\mathrm{G}_{1}$ area in MKN-1 after $36 \mathrm{~h}$ of treatment, whereas the $\mathrm{G}_{2} / \mathrm{M}$ arrest was not observed in MKN-45 and TMK-1. The expression of cell cycle and apoptosis-related proteins showed a correlation with the HIF- $1 \alpha$ expression and the FACS results, which suggested that the level of HIF-1 $\alpha$ correlated with proliferation and apoptosis in human gastric carcinoma cell lines with a possible cell-type specific pattern.
\end{abstract}

\section{Introduction}

The hypoxia-inducible factor- $1 \alpha(\mathrm{HIF}-1 \alpha)$ is a transcription factor and major regulator of the adaptation of cancer cells to hypoxia (1-3). Evidence suggests that HIF-1 $\alpha$ is also a key

Correspondence to: Dr Mitsuhiko Osaki, Division of Organ Pathology, Department of Microbiology and Pathology, Faculty of Medicine, Tottori University, Nishi-cho 86 Yonago, Tottori 683-8503, Japan

E-mail: osamitsu@grape.med.tottori-u.ac.jp

Key words: hypoxia-inducible factor- $1 \alpha$, gastric carcinoma, cell proliferation, apoptosis player in carcinogenesis. Interest in the role of HIF-1 $\alpha$ in cancer has increased remarkably over the last two decades, as this factor activates the transcription of many genes that code proteins involved in several pathways intimately related to cancer (3-5). There is substantial clinical data associating the HIF- $1 \alpha$ protein expression with poor outcomes in patients with a broad range of sporadic cancers, including adenocarcinoma of the breast, lung and colon and squamous cell tumors of the cervix, head and neck as well as malignancies of the central nervous system (CNS) (3,6-9). Thus, the HIF-1 $\alpha$ expression is common in cancer patients. In addition, the increased expression of HIF-1 $\alpha$ correlates significantly with a poor response to chemotherapy and/or radiotherapy in esophageal (10), oropharyngeal (11) and ovarian (7) cancer.

Only a few reports exist on the expression of HIF- $1 \alpha$ in human gastric carcinomas. Zhong et al revealed that HIF- $1 \alpha$ was immunohistochemically detected in cancer cells, but not in normal epithelial cells (6). Urano et al indicated that the overexpression of HIF- $1 \alpha$ correlated with p53 and the vascular endothelial growth factor (VEGF) protein expression immunohistochemically in a human gastric carcinoma (12). According to Park et al, the expression of HIF-1 $\alpha$ was dependent on a radical oxygen species in gastric cancer cells (13). However, the biological significance of the HIF-1 $\alpha$ expression has not been well elucidated in human gastric carcinoma cells (14).

Our previous study revealed the expression of HIF- $1 \alpha$ in the human gastric carcinoma cell line, MKN-1 (15). The expression correlated with cell proliferation and apoptosis as shown by immunocytochemistry, cell viability assays, an apoptotic index, flow cytometry and Western blotting. In the present study, we examined the expression of HIF- $1 \alpha$ and its correlation to cell proliferation in other human gastric carcinoma cell lines, namely, MKN-45 and TMK-1.

\section{Materials and methods}

Cell lines and cell cultures. The human gastric carcinoma cell lines, MKN-45 and TMK-1 (poorly differentiated 
adenocarcinoma), were cultured in Dulbecco's modified Eagle's medium (DMEM, Nissui, Tokyo, Japan) containing $10 \%$ fetal bovine serum (FBS), $100 \mathrm{U} / \mathrm{ml}$ penicillin, $100 \mu \mathrm{g} / \mathrm{ml}$ streptomycin and $292 \mu \mathrm{g} / \mathrm{ml} \mathrm{L}$-glutamine at $37^{\circ} \mathrm{C}$ in $5 \% \mathrm{CO}_{2}$.

Hypoxic treatment. Some metals are known as hypoxic mimicking agents; including cobalt chloride, nickel chloride and desferrioxamine (16). In this study, we used $\mathrm{CoCl}_{2}$ as a hypoxic mimicking agent. For the titration of $\mathrm{CoCl}_{2}$ (Wako, Osaka, Japan), $1 \times 10^{6}$ MKN-45 or TMK-1 cells were seeded in 10-cm diameter dishes $24 \mathrm{~h}$ before being treated with 0 , $100,240,400$ and $500 \mathrm{mM} \mathrm{CoCl}_{2}$.

Cell viability and detection of apoptotic cells. After treatment with or without $\mathrm{CoCl}_{2}$, the MKN-1 cells were washed in PBS(-). Then, cell viability was evaluated by trypan blue staining and the results were normalized to the untreated cells. Apoptotic cells were assessed morphologically by staining with Hoechst 33258 after fixing with Clarke's fixative (ethanol:acetic acid 3:1). An apoptotic index (AI,\%) was calculated as $\mathrm{AI}=100 \mathrm{x}$ apoptotic cells/200 cells.

Immunocytochemistry. Cells were seeded in 6-well plates on which glass coverslips were placed. Six or 36 hours after $\mathrm{CoCl}_{2}$ treatment, the cells were fixed in $4 \%$ paraformaldehyde for $10 \min$ at $4^{\circ} \mathrm{C}$.

Immunocytochemistry was performed using the streptavidin-peroxidase complex (SAB) method with a Histofine SAB-PO (M) immunohistochemical staining kit (Nichirei, Tokyo, Japan). A mouse monoclonal antibody against HIF-1 $\alpha$ (1:500, H1 $\alpha 67$, Novus Biologicals, Littleton, $\mathrm{CO}$ ) was used as the primary antibody. Immunoreactions were visualized with diaminobenzidine and the cells were counterstained with hematoxylin.

SDS PAGE and Western blotting. The SDS-PAGE and Western blotting of the MKN-45 and TMK-1 proteins were performed as previously described (15). The membrane was blotted with anti-HIF-1 $\alpha$ monoclonal antibody (1:500, H1 $\alpha 67$, Novus Biologicals), anti-P27/Kip1 monoclonal antibody (1:500, EA10; Oncogene, Cambridge, MA), anti-SKP2 monoclonal antibody (1:500, Zymed Laboratories Inc., San Francisco, CA), anti-Bcl-xL polyclonal antibody (1:500, Cell Signaling Tech), anti-Bax monoclonal antibody (1:500, Clone 4F11, MBL Co. Ltd., Nagoya Japan), anti-caspase-9 polyclonal antibody (1:500, Santa Cruz Biotechnology), anticleaved-caspase-9 polyclonal antibody (1:500, Cell Signaling, Beverly, MA) and anti- $\beta$-actin monoclonal antibody (1:500, AC15; Sigma, St. Louis, MO).

FACS analysis. The cell cycle distribution was determined by a flow cytometric analysis of DNA content (Becton-Dickinson, San Jose, CA) at $0 \mathrm{~h}$ and after $\mathrm{CoCl}_{2}$ treatment for $36 \mathrm{~h}$. Cell suspensions were prepared by trypsinization and $1 \times 10^{6}$ cells $/ \mathrm{ml}$ were washed twice with PBS(-). The cells were fixed overnight in $10 \mathrm{ml}$ of $70 \%$ ethanol at $4^{\circ} \mathrm{C}$ and incubated with RNase at a concentration of $0.25 \mathrm{mg} / \mathrm{ml}$ at $37^{\circ} \mathrm{C}$ for $1 \mathrm{~h}$. Then, the cells were treated with propidium iodide $(50 \mu \mathrm{g} / \mathrm{ml}$ in PBS) and incubated for $30 \mathrm{~min}$ at $4^{\circ} \mathrm{C}$ in the dark. Before their injection, the samples were passed through a 25 -gauge needle to
A

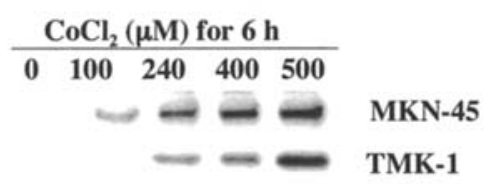

B

Duration of treatment $(\mathbf{h})$

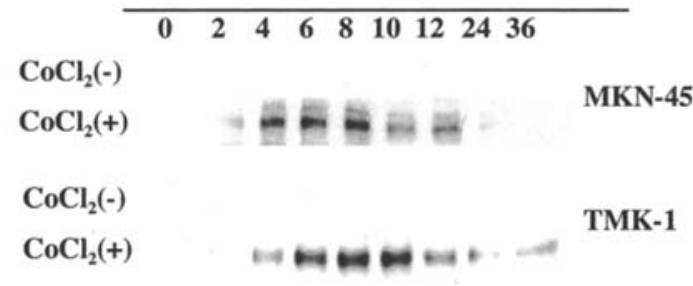

Figure 1. Expression of HIF-1 $\alpha$ in MKN-45 and TMK-1 (A) HIF-1 $\alpha$ expression at increasingly higher doses of $\mathrm{CoCl}_{2}$ for $6 \mathrm{~h}$. (B) After incubation with $500 \mathrm{mM} \mathrm{CoCl}_{2}$, HIF-1 $\alpha$ is expressed with a dual-phase pattern in a timedependent manner, peaking after $6 \mathrm{~h}(\mathrm{MKN}-45)$ or $8 \mathrm{~h}(\mathrm{TMK}-1)$ and then decreasing until $36 \mathrm{~h}$.

prevent cell clumping. DNA histograms were analyzed using lysis-II software (Becton-Dickinson) to evaluate the cell cycle components.

\section{Results}

$\mathrm{CoCl}_{2}$-induced HIF-1 a expression. Treatment with $\mathrm{CoCl}_{2}$ for $6 \mathrm{~h}$ induced the expression of HIF- $1 \alpha$ in MKN-45 and TMK-1 cells in a dose-dependent manner up to a concentration of $500 \mathrm{mM}$ (Fig. 1A). Treatment with $500 \mu \mathrm{M} \mathrm{CoCl}_{2}$ induced the HIF-1 $\alpha$ expression in a time-dependent manner. The pattern of expression was dual phase, with a sharp increase followed by a gradual tapering until $36 \mathrm{~h}$. The peak of expression was at $6 \mathrm{~h}$ in the MKN-45 cells and $8 \mathrm{~h}$ in the TMK-1 cells (Fig. 1B).

Immunocytochemistry. Based on the protein expression of HIF- $1 \alpha$, immunocytochemistry was performed at 0,6 and $36 \mathrm{~h}$ after the $\mathrm{CoCl}_{2}$ treatment in the MKN-45 and TMK-1 cells (Fig. 2A). In both cell lines, the HIF-1 $\alpha$-positive cells made up less than $10 \%$ of the untreated cells, in which immunoreactivity was observed mostly in the cytoplasm. On the other hand, the rates of the HIF-1 $\alpha$-positive cells were significantly increased in the treated cells after $6 \mathrm{~h}$ and were relatively low after $36 \mathrm{~h}$ in both MKN-45 and TMK-1. The viability index of the treated cells also showed a sharp increase until $6 \mathrm{~h}$ followed by a gradual tapering until $36 \mathrm{~h}$, the relative value being $119.3 \mathrm{vs}$. $41.0 \%$ in MKN-45 and 131.4 vs. $11.1 \%$, in TMK-1 (Fig. 2B). This pattern correlated with the HIF-1 $\alpha$ protein expression (Fig. 1B) and viability of the two cell lines under $\mathrm{CoCl}_{2}$ treatment (Fig. 2B). Notably, nuclear immunoreactivity was evident in the $\mathrm{CoCl}_{2}$-treated cells, but not in the untreated cells (Fig. 2A).

Cell viability, FACS analysis and the cell cycle-related protein expression. After $36 \mathrm{~h}$, the FACS analysis showed an increase in the pre- $\mathrm{G}_{1}$ fraction in the $\mathrm{CoCl}_{2}$-treated $\mathrm{MKN}-45$ cells and more obviously in the TMK-1 cells, while no increase 
A MKN-45

Immunocytochemistry
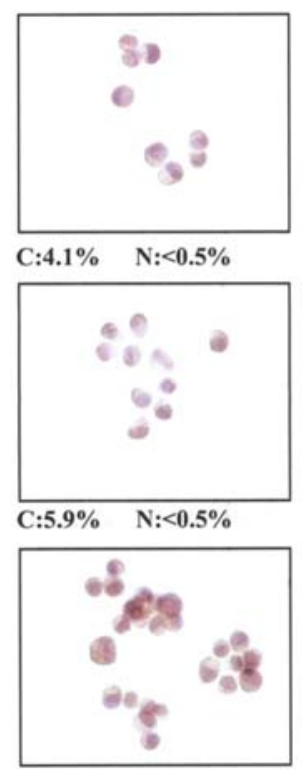

C: $8.1 \% \quad \mathrm{~N}:<1.0 \%$
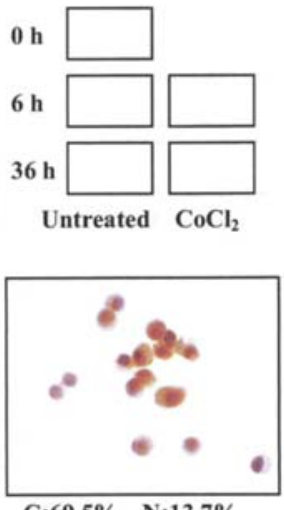

C:69.5\% N:13.7\%

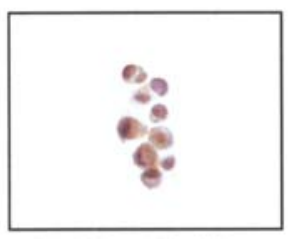

C: $7.2 \% \quad \mathrm{~N}: 8.6 \%$
TMK-1

Immunocytochemistry
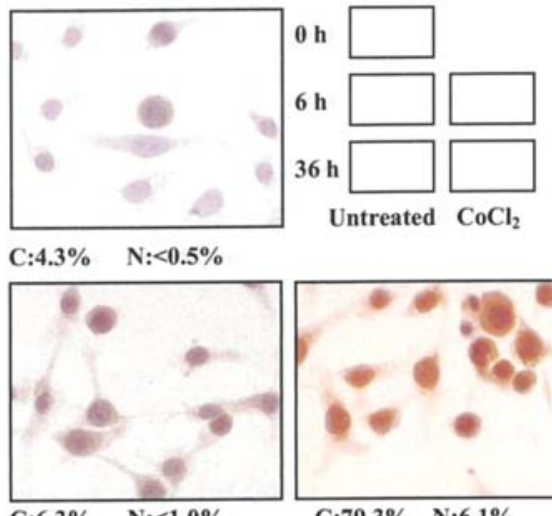

$\mathrm{C}: 6.3 \% \quad \mathrm{~N}:<1.0 \%$

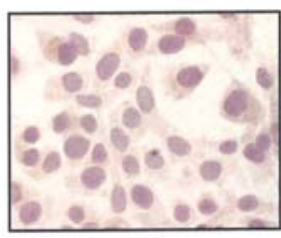

C: $9.3 \% \quad \mathrm{~N}: 1.0 \%$

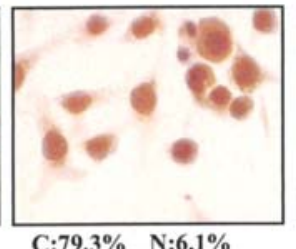

C: $79.3 \% \quad \mathrm{~N}: 6.1 \%$

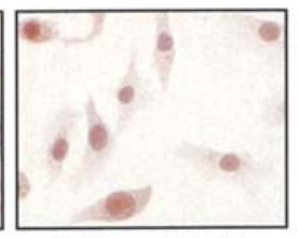

C: $17.2 \% \quad \mathrm{~N}: 12.3 \%$

B

MKN-45

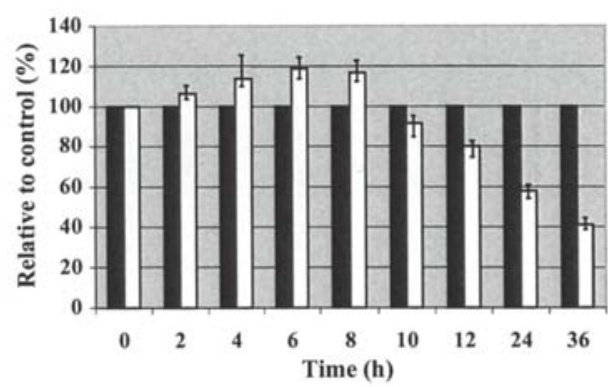

TMK-1

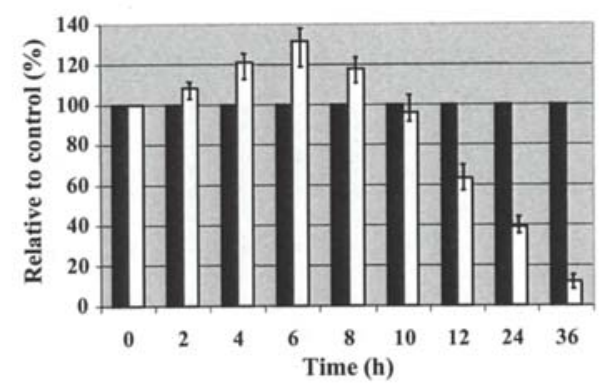

Figure 2. Immunocytochemistry and cell viability index. (A) Immunocytochemistry shows cytoplasmic immunoreactions in the untreated cells at all the indicated time points with relatively weak positivity. Significant immunoreactivity in the nuclei is detected in the treated cells, especially after $6 \mathrm{~h}$. (C: $\%$ of cytoplasmic immunoreactions; $\mathrm{N}$ : \% of nuclear immunoreactions). (B) Cell viability index shows an increase until $6 \mathrm{~h}$, followed by a decrease until $36 \mathrm{~h}$. The graph shows averages from triplicate data of three separate experiments. ( $\mathbf{\square}$ : $\mathrm{CoCl}_{2}$ untreated cells as a relative control, $\square$ : $\mathrm{CoCl}_{2}$ treated cells).

was evident in the untreated cells (Fig. 3A). No $\mathrm{G}_{2} / \mathrm{M}$ arrest was observed in either cell lines. These results suggested that the decrease in the expression of HIF- $1 \alpha$ was correlated with the induction of apoptosis in the $\mathrm{CoCl}_{2}$-treated $\mathrm{MKN}-45$ and TMK-1 cells.

As shown in Fig. 3B, the Western blot analysis revealed that the expression of SKP2 had a similar pattern to that of HIF-1 $\alpha$. On the other hand, the P27/Kip1 expression increased significantly after $36 \mathrm{~h}$ in the treated cells, which showed an inverse correlation with the alteration of the HIF-1 $\alpha$ expression. The expression of these proteins was also suggested to correlate with the results of the FACS analysis $36 \mathrm{~h}$ after the treatment.

Apoptotic index and expression of apoptosis-related proteins. Apoptosis was detected morphologically by Hoechst 33258 staining (Fig. 3C). A significant number of apoptotic cells were observed among the $\mathrm{CoCl}_{2}$-treated MKN-45 and TMK-1 cells at $36 \mathrm{~h}$ compared to the untreated cells. The apoptotic indices also started to increase at $8 \mathrm{~h}$ until $36 \mathrm{~h}$ in the two cell lines in a time-dependent manner (Fig. 3D). These patterns were relevant to those of the cell viability indices. Furthermore, it is reasonable to assume that the increase of the apoptotic index correlated with the decrease of the HIF-1 $\alpha$ expression.

In both lines, Western blotting showed the expression of $\mathrm{Bcl}-2$ and Bcl-xL, anti-apoptotic factors, in a similar pattern to that of HIF-1 $\alpha$. Moreover, the pro-apoptotic factors, Bax and cleaved-caspase-9, showed an increase in a time-dependent manner, coinciding with the decrease of the HIF-1 $\alpha$ expression (Fig. 3E). Overall, the patterns of Bcl-2, Bcl-xL, Bax and the cleaved-caspase- 9 expression suggested a possible role for apoptosis in the correlation of the HIF-1 $\alpha$ expression with MKN-45 and TMK-1 cell proliferation.

\section{Discussion}

Previously we reported a correlation between the $\mathrm{CoCl}_{2}$ induced HIF-1 $\alpha$ expression and cell proliferation and apoptosis in the cell line, MKN-1 (15). The relationship was evidenced 
A

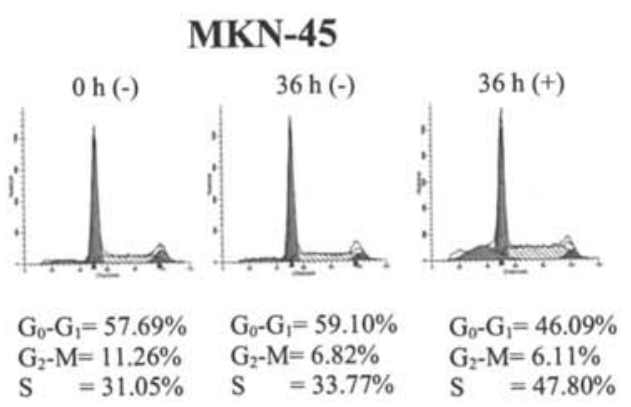

TMK-1
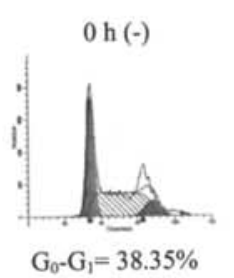
$\mathrm{G}_{2}-\mathrm{M}=9.95 \%$ $\mathrm{S}=51.70 \%$

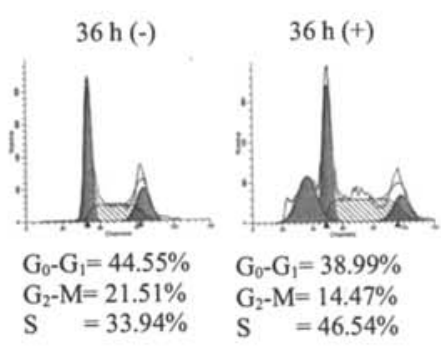

B

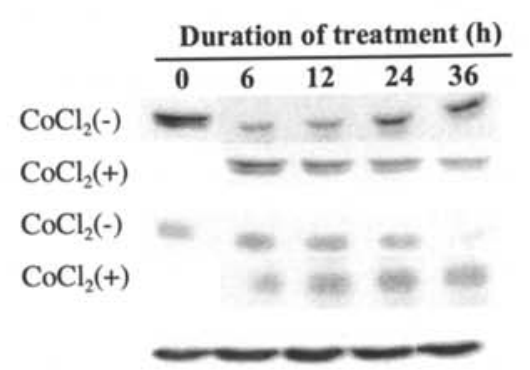

SKP2

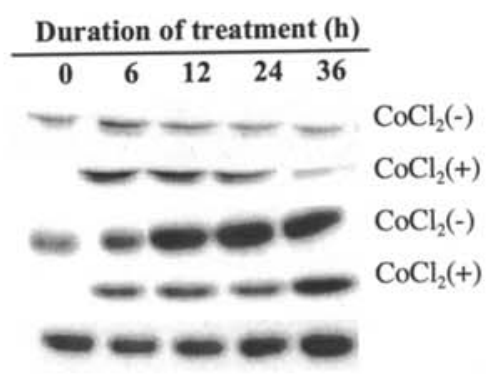

C

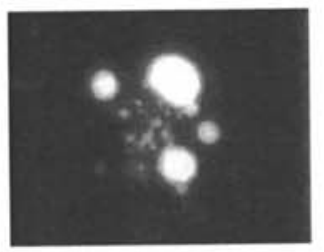

D

MKN-45

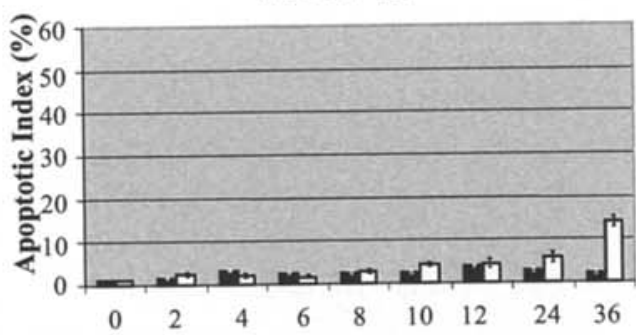

$\mathbf{E}$

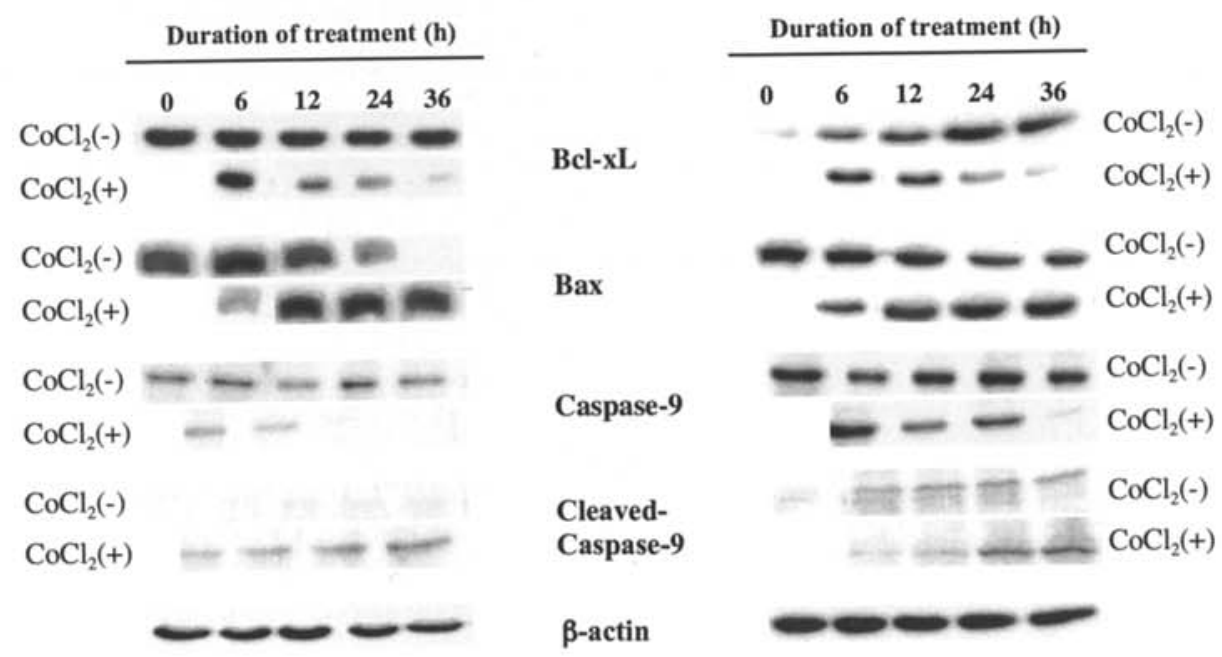

Figure 3. Detection of apoptosis and expression of cell cycle and apoptosis-related proteins. (A) After $36 \mathrm{~h}$ of $\mathrm{CoCl}_{2}$ treatment, FACS shows an increase in the pre- $\mathrm{G}_{1}$ (apoptotic) fraction in MKN-45 and more significantly in TMK-1. (B) Western blotting shows that the HIF-1 $\alpha$ expression correlates with the SKP2 and P27/Kip1 expression, under $\mathrm{CoCl}_{2}$ treatment. (C) Apoptotic bodies were detected by Hoechst 33258 staining after $36 \mathrm{~h}$ of $\mathrm{CoCl}_{2}$ treatment. (D) The apoptotic index shows the correlation with the HIF-1 $\alpha$ expression; the increase starting after $8 \mathrm{~h}$ of treatment and coinciding with the decrease in the HIF-1 $\alpha$ expression. The graph shows averages from triplicate data of three separate experiments. ( $\square$ : $\mathrm{CoCl}_{2}$ untreated cells, $\square$ : $\mathrm{CoCl}_{2}$ treated cells). (E) Western blot analysis shows that the expression of HIF-1 $\alpha$ correlates with that of Bcl-xL (anti-apoptotic) as well as Bax and cleaved-caspase-9 (pro-apoptotic). 
by immunocytochemistry, a cell viability and apoptotic index, FACS analysis and Western blotting. The data suggested that the expression level of HIF- $1 \alpha$ regulates proliferation in human gastric carcinoma cells. This may also be the case in other human gastric carcinoma cell lines.

The present study detected the $\mathrm{CoCl}_{2}$-induced HIF- $1 \alpha$ expression by Western blotting as well as immunocytochemistry in two human gastric carcinoma cell lines, MKN-45 and TMK-1. Notably, the pattern of expression was similar to that obtained in MKN-1 cells. A difference was noted when the expression peaked (MKN-1, $4 \mathrm{~h}$ vs. MKN-45 and TMK-1, $6 \mathrm{~h}$ ), suggesting that it might be caused by a cell-type-specific property. Overall, the expression pattern of HIF-1 $\alpha$ induced by $\mathrm{CoCl}_{2}$ treatment was considered to be similar in all of the human gastric carcinoma cells examined in our studies. It is indicated that $\mathrm{CoCl}_{2}$ treatment for a short time induced a transient up-regulation of the HIF-1 $\alpha$ expression, but the level decreased with long-term exposure to $\mathrm{CoCl}_{2}$, which induced environment-mimicking hypoxic conditions. The decrease that followed the initial transient up-regulation suggested a negative-feedback mechanism on the prolonged exposure to hypoxia $(17,18)$.

Moreover, cell viability in each cell line depended on the HIF-1 $\alpha$ expression, i.e., down-regulation of the expression induced inhibition of cell growth due to apoptosis in human gastric carcinoma cells. An increase in the pre- $\mathrm{G}_{1}$ fraction after $36 \mathrm{~h}$ of $\mathrm{CoCl}_{2}$ treatment was also shown by an increase in the apoptotic indices of the MKN-45 and TMK-1 cells coinciding with the decrease of the HIF- $1 \alpha$ expression. An up-regulation of the $\mathrm{Bcl}-\mathrm{xL}$ expression occurred in the two cell types in correlation with the increase of the HIF- $1 \alpha$ expression as well as a higher cell viability, while both cell types showed a down-regulation of Bcl-xL and an upregulation of Bax and cleaved-caspase- 9 expression and an increase in the apoptotic index with the decrease of HIF-1 $\alpha$. These patterns were similar to that of the MKN-1 cells (15), supporting the correlation between the HIF-1 $\alpha$ expression and apoptosis suggested by other reports $(19,20)$.

$\mathrm{CoCl}_{2}$-treated MKN-45 cells had a rather high viability index while the TMK-1 cells showed no significant difference after $36 \mathrm{~h}$ compared to the MKN-1 cells (15). Previously, $\mathrm{CoCl}_{2}$-treated MKN-1 cells showed both a marked $\mathrm{G}_{2} / \mathrm{M}$ arrest and an increase in apoptotic areas after $36 \mathrm{~h}$ (15). In the present study, neither the MKN-45 nor TMK-1 cells showed obvious cell cycle arrest after $36 \mathrm{~h}$ of treatment. This difference in results may be explained by the expression of SKP2 and P27/Kip1. The changes in the SKP2 and P27/Kip1 expression in the $\mathrm{CoCl}_{2}$-treated MKN-45 and TMK-1 cells were less prominent, whereas a drastic induction of P27/Kip1 expression was detected with the down-regulation of the HIF-1 $\alpha$ expression in the $\mathrm{CoCl}_{2}$-treated MKN-1 cells (15), suggesting that the lack of $\mathrm{G}_{2} / \mathrm{M}$ arrest in the $\mathrm{CoCl}_{2}$-treated MKN-45 and TMK-1 was due to an insufficient P27/Kip1 expression. Further studies are necessary to elucidate the relationship between the P27/Kip1 expression and HIF-1 $\alpha$.

Both the present and previous study (15) showed that a down-regulation of the HIF-1 $\alpha$ expression of long-term exposure to $\mathrm{CoCl}_{2}$ may suppress proliferation through apoptosis in human gastric carcinoma cells. The results indicate that HIF-1 $\alpha$ may be a potential molecular target in the treatment of human gastric carcinoma, though further study is necessary to elucidate the mechanism(s) involved.

\section{References}

1. Wang GL, Jiang BH, Rue EA, et al: Hypoxia-inducible factor 1 is a basic-helix-loop-helix-PAS heterodimer regulated by cellular O2 tension. Proc Natl Acad Sci USA 92: 5510-5514, 1995.

2. Kizaka-Kondoh S, Inoue M, Harada $\mathrm{H}$ and Hiraoka M: Tumor hypoxia: a target for selective cancer therapy. Cancer Sci 94: 1021-1028, 2003.

3. Semenza GL: Targeting HIF-1 $\alpha$ for cancer therapy. Nat Rev Cancer 3: 731-732, 2003.

4. Harris AL: Hypoxia: a key regulatory factor in tumor growth. Nat Rev Cancer 2: 38-47, 2002.

5. Lopez-Lazaro M: HIF-1, hypoxia-inducible factor or dysoxiainducible factor? FASEB J 20: 828-832, 2006.

6. Zhong H, Chiles K, Feldser D, et al: Overexpression of hypoxia-inducible factor 1alpha in common human cancers and their metastases. Cancer Res 59: 5830-5835, 1999.

7. Birner P, Schindl M, Obermair A, Plank C, Breitenecker G and Oberhuber G: Overexpression of hypoxia-inducible factor 1alpha is a marker for an unfavorable prognosis in early-stage invasive cervical cancer. Cancer Res 60: 4693-4618, 2000.

8. Krokawa T, Miyamoto M, Kato K, et al: Overexpression of hypoxia-inducible-factor 1alpha (HIF-1alpha) in oesophageal squamous cell carcinoma correlates with lymph node metastasis and pathologic stage. Br J Cancer 89: 1042-1047, 2003.

9. Semenza GL: Development of novel therapeutic strategies that target HIF-1. Expert Opin Ther Targets 10: 267-280, 2006.

10. Koukourakis MI, Giatromanolaki A, Skarlatos J, et al: Hypoxia inducible factor (HIF-1alpha and HIF-1beta) expression in early esophageal cancer and response to photodynamic therapy and radiotherapy. Cancer Res 61: 1830-1832, 2001.

11. Aebersold DM, Burri P, Beer KT, et al: Expression of hypoxiainducible factor-1alpha - a novel predictive and prognosis parameter in the radiotherapy of oropharyngeal cancer. Cancer Res 61: 2911-2916, 2001

12. Urano N, Fujiwara Y, Doki Y, et al: Overexpression of hypoxiainducible factor-1alpha in gastric adenocarcinoma. Gastric Cancer 9: 44-49, 2006.

13. Park J, Kim T, Jong H, et al: Gastric epithelial reactive species prevent normoxic degradation of hypoxia-inducible factor- $1 \alpha$ in gastric cancer cells. Clin Cancer Res 9: 433-440, 2003.

14. Griffiths EA, Pritchard SA, Welch IM, Price PM and West CM: Is the hypoxia-inducible factor- $1 \alpha$ pathway important in gastric cancer? Eur J Cancer 41: 2972-2805, 2005.

15. Ardyanto TD, Osaki M, Tokuyasu N, Nagahama Y and Ito H: $\mathrm{CoCl}_{2}$-induced HIF-1alpha expression correlates with proliferation and apoptosis in MKN-1 cells: a possible role for the PI3K/Akt pathway. Int J Oncol 29: 549-555, 2006.

16. Goldberg MA, Dunning SP and Bunn HF: Regulation of erythropoietin gene: evidence that the oxygen sensor is a heme protein. Science 242: 1412-1414, 1988.

17. D'Angelo G, Duplan E, Boyer N, Vigne P and Frelin C: Hypoxia up-regulates prolyl hydroxylase activity: a feedback mechanism that limits HIF- 1 responses during reoxygenation. J Biol Chem 278: 38183-38187, 2003.

18. Dann CE, Bruick RK and Deisenhofer J: Structure of factorinhibiting hypoxia-inducible factor 1: An asparaganyl hydroxylase involved in the hypoxic response pathway. Proc Natl Acad Sci USA 99: 15351-15356, 2002.

19. Weinmann M, Jendrossek V, Handrick R, Guner D, Goecke B and Belka C: Molecular ordering of hypoxia-induced apoptosis: critical involvement of the mitochondrial death pathway in a FADD/caspase-8 independent manner. Oncogene 23: 3757-3769, 2004.

20. Lee M, Kim J, Suk K and Park J: Identification of the hypoxiainducible factor- $1 \alpha$-responsive HGTD-P gene as a mediator in the mitochondrial apoptotic pathway. Mol Cell Biol 24: 3918-3927, 2004. 